\title{
High Frequency of Brown Stem Rot Resistance in Soybean Germ Plasm from Central and Southern China
}

\author{
M. S. Bachman, Graduate Research Fellow, and C. D. Nickell, Professor of Plant Breeding, Department of Crop \\ Sciences, University of Illinois, Urbana 61801
}

\begin{abstract}
Bachman, M. S., and Nickell, C. D. 2000. High frequency of brown stem rot resistance in soybean germ plasm from central and southern China. Plant Dis. 84:694-699.

In an effort to identify new sources of resistance to brown stem rot, caused by Phialophora gregata, 829 soybean accessions originating from 14 provinces in central and southern China and ranging in maturity from group IV to group VIII were obtained from the USDA Soybean Germplasm Collection. All accessions were inoculated in sequential evaluations in the greenhouse with three isolates of $P$. gregata. Putatively resistant accessions were compared statistically with resistant and susceptible standards. Two hundred forty-one, or approximately $29 \%$ of the accessions evaluated, were resistant to all three isolates of $P$. gregata. The percentage of resistant accessions varied among provinces, with the highest percentages identified in the provinces of Anhui, Gansu, Jiangsu, and Sichuan. Resistance to brown stem rot was not associated with maturity of the accessions or presence of soybean mosaic virus. These resistant accessions could be utilized as sources of brown stem rot resistance through integration of northern and southern soybean germ plasm.
\end{abstract}

Brown stem rot (BSR), caused by Phialophora gregata (Allington \& Chamberlain) W. Gams, is a fungal disease of soybean (Glycine max (L.) Merr.) that has been observed in soybean producing regions of the United States $(2,11,26,33,39)$. Symptoms of BSR include browning of the vascular and pith tissue and foliar chlorosis-necrosis. Yield reductions up to $38 \%$ have been reported under environmental conditions that favor the disease $(4,19$, $32,46,55)$.

There have been several efforts to identify BSR-resistant germ plasm since the first documentation of the disease in 1944. Chamberlain and Bernard (6) conducted BSR evaluations on more than 2,000 accessions between 1947 and 1952 and identified one resistant line, PI 84946-2. Tachibana and Card (51) later confirmed resistance in four accessions (PI 86150, PI 88820 N, PI 90138, PI 95769) originally selected by Allington and Chamberlain. Nelson et al. (36) screened over 3,400 accessions from the northern portion of the USDA Soybean Germplasm Collection between 1981 and 1984. Using field and

Corresponding author: C. D. Nickell

E-mail: cnickell@uiuc.edu

Contribution of the Illinois Agricultural Experiment Station. Research supported in part by Illinois Soybean Program Operating Board and United Soybean Board.

Accepted for publication 9 March 2000.

Publication no. D-2000-0411-02R

(c) 2000 The American Phytopathological Society greenhouse evaluation, they identified putatively resistant types in maturity groups 0 to IV, although none had resistance superior to previously identified sources. Recently, Bachman et al. (3) evaluated 559 accessions from central China and identified 13 accessions in maturity groups II to IV with levels of resistance equal to previously identified sources.

Genetic analyses on BSR resistance sources identified in germ plasm evaluations have indicated that resistance is conditioned by one or a few genes. Monogenic resistance to BSR has been identified in three sources: Rbsl in L78-4094 (germ plasm line derived from PI 84946-2) (22), $R b s 2$ in PI 437833 (22), and $R b s 3$ in PI 437970 (56). Sebastian and Nickell (44) found that resistance in PI 84946-2 was conditioned by two nonallelic genes (later identified as Rbsl [22] and Rbs3 [14]), and Waller et al. (52) proposed that resistance in cv. Asgrow A3733 was the result of the combined action of a major gene and a modifier gene.

Although monogenic resistance has been identified and utilized, it has not provided immunity to $P$. gregata, and in some instances resistant lines have appeared susceptible in the field $(36,56)$ and greenhouse (48). The existence of variability in $P$. gregata $(18,31,40,48,57)$ and the frequent use of BSR-resistant cultivars may promote selection for virulence in the pathogen and subsequent ineffectiveness of resistant genotypes. The need for stable resistance to BSR has encouraged breeders and geneticists to search for new sources.

Field evaluations of soybean germ plasm for BSR reaction have proven difficult.
Chamberlain and Bernard (6) noted large environmental variability in BSR reaction that confounded selection for resistant genotypes. Nelson et al. (36) observed inconsistent responses across environments, possibly due to differences in pathogenicity among $P$. gregata isolates, differing rates of symptom development of different soybean genotypes, the presence of confounding symptoms produced by other pathogens, variability in environmental factors, or a combination of the above. Bachman et al. (3) also noted difficulties evaluating germ plasm in the field because of high variability in, or lack of, BSR symptom development.

Germ plasm evaluation for BSR reaction can be conducted in the greenhouse to reduce variability commonly associated with field screening $(3,44,45,46)$. Variation in agronomic factors such as plant spacing (37), fertility level (53), and moisture level (32) can be minimized through greenhouse evaluation. More importantly, variation in pathogenicity and inoculum density of the fungus (1) can be reduced by inoculation with a known concentration of a single isolate. As a result, BSR-resistant and -susceptible types can be differentiated more easily. Sebastian et al. (46) found that greenhouse foliar symptoms were highly correlated with field reactions when foliar symptoms were present on susceptible standards. They also noted that selection in the greenhouse based on foliar symptoms was useful in identifying soybeans with BSR resistance in the field. In a separate study conducted on efficiency of greenhouse screening, Sebastian et al. (45) found that broad sense heritability estimates were two to three times larger for foliar symptoms than for stem symptoms. The lower heritability estimate for stem symptoms was likely the result of error associated with quantitation of stem symptoms. Nelson et al. (36) found that consistent foliar symptoms were present at only one of multiple field locations, and that results from that location agreed more closely with greenhouse results than with any other field location. Therefore, previous research has demonstrated that greenhouse screening based on foliar symptoms can both reduce environmental variation associated with field evaluation and accurately predict the response of soybean genotypes to BSR disease pressure in the field.

New sources of resistance would be useful as gene donors for both unique mono- 
genic resistance and pyramid-type resistance in new cultivars. The latter strategy could increase stability of host resistance across $P$. gregata isolates $(52,57)$. Plant introductions have been an important source of disease resistance genes in soybean, including those for brown stem rot resistance $(14,22,57)$. However, all BSRresistant accessions identified to date have been in maturity group IV or earlier (3,6,36,51). With increasing evidence of genetic diversity among northern and southern U.S. soybean germ plasm groups $(16,17)$, it is likely that future soybean improvement will involve integration of these groups. Knowledge of disease resistance traits in southern germ plasm may therefore facilitate improvement of northern germ plasm. The objective of this study was to evaluate the reaction of 829 maturity group IV to VIII Chinese soybean accessions to multiple isolates of $P$. gregata in an attempt to identify unique sources of resistance.

\section{MATERIALS AND METHODS}

Eight hundred twenty-nine soybean accessions originating from 14 provinces in central and southern China were obtained from the USDA Soybean Germplasm Collection at the University of Illinois at Urbana-Champaign for evaluation (Table 1). Soybean genotypes with known BSR reactions were selected to be evaluated with the accessions to monitor disease development and to serve as BSR-reaction references. Seven resistant standards (PI 84946-2, PI 86150, PI 567296B, PI 567552, L78-4094, PI 437833, and PI 437970) and five susceptible standards (cvs. Louisiana Green, Century 84, and Clark 63, and PI 567445B and PI 567614D) were included. Brown stem rot reactions for all standards were verified in previous germ plasm evaluations $(3,6,36,51)$. Resistant and susceptible standards were selected from a range of maturity groups (I to VIII) in an attempt to represent maturities of the accessions being evaluated. However, the lack of published information on BSR reactions of soybean genotypes in maturity groups V to VIII (likely due to minimal economic loss caused by BSR in those maturity regions) made it impossible to include standards from all maturity groups.

Inoculum of $P$. gregata was prepared in liquid cultures as described by Bachman et al. (3). Briefly, cultures were initiated by transferring three agar plugs (approximately $2.7 \mathrm{~cm}^{3}$ ) containing hyphal tips of an active culture from soybean stem agar minimal medium (1) to $100 \mathrm{ml}$ of soybean seed broth (100 $\mathrm{g}$ of soybean seed per liter of water steamed, strained, and autoclaved). Both stem agar and seed broth were derived from tissue of susceptible cultivar Century 84. Stationary liquid cultures were incubated at $24^{\circ} \mathrm{C}$ in the dark. After 4 weeks, seed broth cultures of $P$. gregata were ground for $75 \mathrm{~s}$ in a blender at high speed. The concentration of mycelial fragments and conidia was determined using a hemacytometer; mycelial fragments of all sizes were included in counts. Ground cultures were then diluted with distilled water to a concentration of $1.2 \times 10^{6}$ propagules per ml. Carboxymethyl cellulose was blended into the suspension at a rate of $7.5 \mathrm{~g} /$ liter to act as a sticking agent.

Accessions were evaluated in the greenhouse from October through May, 1997 to 1999, using the root-dip inoculation method of Sebastian and Nickell (44) as modified by Bachman et al. (3). Seed was germinated in commercial grade sand in 10-cm-diameter plastic pots and grown for 14 days (V1 growth stage [15]) at ambient temperatures ranging from 18 to $24^{\circ} \mathrm{C}$. Sand was rinsed from the roots of seedlings with tap water. For each accession, two to five healthy-appearing seedlings were selected, and the roots were blotted dry using paper towels. The entire root systems of seedlings were then dipped for approximately $3 \mathrm{~s}$ into a beaker containing $50 \mathrm{ml}$ of $P$. gregata inoculum. The group of seedlings was removed from the inoculum and placed into a 6- to $8-\mathrm{cm}$ deep, hemispherical depression in steamtreated 1:1 sand:topsoil mixture filling a 15-cm-diameter, steam-sterilized clay pot.
The remaining inoculum was then poured over the roots of the seedlings at a rate of $10 \mathrm{ml}$ per plant, and the roots were covered with the 1:1 sand:topsoil mixture to a level 1 to $2 \mathrm{~cm}$ below the cotyledons. Plants received supplemental lighting from metal halide and sodium lamps to maintain a 13$\mathrm{h}$ photoperiod. Plants were grown at an average nighttime ambient temperature of $18^{\circ} \mathrm{C}$ and an average daytime ambient temperature of $24^{\circ} \mathrm{C}$. All entries received approximately $300 \mathrm{ml}$ of water daily. Pots were fertilized weekly with $150 \mathrm{ml}$ of a nutrient solution containing $0.121 \mathrm{~g}$ of $\mathrm{N}$, $0.112 \mathrm{~g}$ of $\mathrm{P}, 0.107 \mathrm{~g}$ of $\mathrm{K}, 0.000044 \mathrm{~g}$ of $\mathrm{B}, 0.00022 \mathrm{~g}$ of chelated $\mathrm{Fe}$, and $0.00011 \mathrm{~g}$ of chelated $\mathrm{Cu}, \mathrm{Mn}$, and $\mathrm{Zn}$.

Soybean accessions and standard genotypes were screened for brown stem rot reaction using three $P$. gregata isolates previously tested for the ability to cause foliar BSR symptoms on susceptible genotypes. Accessions were screened sequentially with one replicate of one isolate (designated here as isolates $\mathrm{A}, \mathrm{B}$, and $\mathrm{C}$ for discussion) of $P$. gregata per evaluation, so that the order of screening events occurred as follows: isolate $\mathrm{A}$, replicate 1 ; isolate $\mathrm{B}$, replicate 1 ; isolate $C$, replicate 1 ; isolate $A$, replicate 2 ; isolate $B$, replicate 2 ; isolate $C$, replicate 2 . In order to evaluate a large number of accessions with the limited resources available, susceptible genotypes were culled during the screening process. Therefore, only putatively resistant accessions and standards were included in subsequent screening events. This procedure required the use of both a qualitative and a simple quantitative method of susceptibility determination. An individual plant within a replicate was rated susceptible if foliar BSR symptoms had progressed to or above the first trifoliolate node and resistant if the plant had no symptoms or symptoms that had not progressed to the first trifoliolate node. This method of susceptibility determination for individual plants was used by Hanson et al. (22) in a genetic study that identified BSR resistance genes Rbsl and Rbs2.

Table 1. Province of origin, number of accessions in each maturity group, total number of accessions, number of resistant accessions, and percentage of resistant accessions from each province for Chinese accessions evaluated for brown stem rot resistance

\begin{tabular}{|c|c|c|c|c|c|c|c|c|}
\hline \multirow{2}{*}{$\begin{array}{l}\text { Province of } \\
\text { origin in China }\end{array}$} & \multicolumn{5}{|c|}{ Maturity group } & \multirow[b]{2}{*}{ Total } & \multirow[b]{2}{*}{ Resistant } & \multirow[b]{2}{*}{$\%$ resistant } \\
\hline & IV & $\mathbf{V}$ & VI & VII & VIII & & & \\
\hline Anhui & 2 & 4 & 32 & 32 & 3 & 73 & 23 & 32 \\
\hline Gansu & 0 & 43 & 1 & 0 & 0 & 44 & 16 & 36 \\
\hline Guangdong & 3 & 0 & 4 & 1 & 1 & 9 & 6 & 67 \\
\hline Hebei & 0 & 4 & 0 & 0 & 0 & 4 & 2 & 50 \\
\hline Henan & 0 & 15 & 0 & 0 & 0 & 15 & 9 & 60 \\
\hline Hubei & 4 & 37 & 66 & 52 & 15 & 174 & 28 & 16 \\
\hline Jiangsu & 34 & 51 & 53 & 69 & 16 & 223 & 83 & 37 \\
\hline Ningxia & 0 & 2 & 0 & 0 & 0 & 2 & 1 & 50 \\
\hline Shaanxi & 0 & 54 & 2 & 0 & 0 & 56 & 10 & 18 \\
\hline Shanxi & 0 & 9 & 0 & 0 & 0 & 9 & 2 & 22 \\
\hline Shandong & 0 & 3 & 0 & 0 & 0 & 3 & 0 & 0 \\
\hline Shanghai & 0 & 0 & 2 & 5 & 0 & 7 & 3 & 43 \\
\hline Sichuan & 68 & 20 & 19 & 19 & 8 & 134 & 41 & 31 \\
\hline Zhejiang & 0 & 1 & 8 & 37 & 30 & 76 & 17 & 22 \\
\hline Total & 111 & 243 & 187 & 215 & 73 & 829 & 241 & \\
\hline
\end{tabular}


A replicate (two to five plants) of an accession was rated susceptible if it contained two or more susceptible plants and resistant if it contained no more than one susceptible plant. Although somewhat arbitrary, this method of susceptibility determination was justified for the following reasons. First, soybean accessions in the USDA Germplasm Collection are purified to increase homogeneity (35), so individual plants within an accession would be expected to have the same genotype and BSR reaction. Second, a BSRsusceptible response has been considered a positive reaction to inoculation (44) and thus represents the true response of the accession. Third, BSR foliar symptoms have been shown to be highly heritable in a greenhouse environment (45), and it has been suggested that a single replicate of greenhouse data may be sufficient to identify BSR-susceptible breeding lines (46). Finally, two BSR-susceptible plants were rarely observed in replicates containing resistant standards (data not included). Therefore, this method of susceptibility determination was used to cull susceptible genotypes from the pool of accessions throughout the evaluation process. Putatively resistant accessions that survived screening with two replicates of each of the three isolates were subjected to an analysis of variance and LSD test; these data will be discussed later in this section.

Seed quality of soybean accessions evaluated in this study was highly variable. Due to limited quantities of seed, poor germination, or poor seedling vigor of some accessions, a small proportion of pots contained as few as two plants at the time of rating. In some instances, these pots contained one susceptible plant and one resistant plant. Based on the method of susceptibility determination, the accessions in these pots were declared putatively resistant. However, these accessions were challenged with an additional replication using the same $P$. gregata isolate, as well as two replications using two additional isolates. Therefore, an inconsistent reaction of plants within one replicate was not representative of the overall reaction of the accession.

In the first screening event, all accessions and standards were inoculated with a single monoconidial isolate of $P$. gregata, designated $\mathrm{PgOh} 2$ (obtained from Lynn Gray, USDA-ARS, University of Illinois). This isolate was used in a previous germ plasm evaluation because it consistently produced BSR foliar symptoms on susceptible genotypes (3). Plants were evaluated for BSR reaction 5 to 6 weeks after inoculation (R1 to R3 growth stage [15]). Individual plants were rated for height of progression of foliar symptoms (proportion of total plant nodes with foliar symptoms). These individual plant ratings were used for culling of susceptible genotypes, as mentioned above, and they were averaged to obtain a replicate mean for use in later statistical analyses. Accessions exhibiting a resistant reaction (no more than one plant per pot with BSR foliar symptoms to or above the first trifoliolate node) to isolate $\mathrm{PgOh} 2$ were then inoculated in sequential events with isolates of $P$. gregata, designated SS\#1 and P106. The isolate SS\#1 was isolated by M. S. Bachman from the soybean cultivar Century 84 near Ottawa, $\mathrm{IL}$, in 1994 (unpublished), and P106 was obtained from T. C. Harrington, Iowa State University. Both of these isolates had been tested and verified as highly pathogenic defoliating isolates of $P$. gregata prior to this study (unpublished data). Accessions with resistant reactions to one replicate of each of isolates $\mathrm{PgOh} 2$, SS\#1, and P106 were then screened in sequential inoculation events with a second replication of each of the three isolates.

Throughout the six screening events (two replications of three isolates), any accession exhibiting a susceptible BSR reaction phenotype (foliar symptoms to or

Table 2. Reaction of standard soybean genotypes to inoculation with Phialophora gregata isolates PgOh2, SS\#1, and P106

\begin{tabular}{lccccc}
\hline & & \multicolumn{3}{c}{ Reaction to isolate $^{\mathbf{a}}$} & \\
\cline { 3 - 5 } Standard & MG $^{\mathbf{b}}$ & PgOh2 & SS\#1 & P106 & Avg. $^{\mathbf{c}}$ \\
\hline L78-4094 & II & 0.24 & 0.09 & 0.10 & 0.14 \\
PI 437833 & I & 0.04 & 0.00 & 0.00 & 0.01 \\
PI 437970 & II & 0.00 & 0.00 & 0.00 & 0.00 \\
PI 567552 & IV & 0.08 & 0.00 & 0.00 & 0.03 \\
PI 567296B & IV & 0.00 & 0.00 & 0.00 & 0.00 \\
PI 849462 & IV & 0.00 & 0.00 & 0.00 & 0.00 \\
PI 86150 & IV & 0.00 & 0.00 & 0.00 & 0.00 \\
Century 84 & II & 0.71 & 0.63 & 0.55 & 0.63 \\
Clark 63 & IV & 0.59 & 0.44 & 0.38 & 0.47 \\
PI 567614D & IV & 0.80 & 0.44 & 0.55 & 0.59 \\
PI 567445B & IV & 0.63 & 0.73 & 0.24 & 0.53 \\
Louisiana Green & VIII & 0.08 & 0.00 & 0.12 & 0.07 \\
LSD (P $P$ 0.05) & & & & & 0.09 \\
\hline
\end{tabular}

a Reaction of accessions to defoliating isolates of $P$. gregata designated PgOh2, SS\#1, and P106.

Value represents the proportion of total plant nodes with a leaf exhibiting brown stem rot foliar chlorosis-necrosis, averaged over two replications.

${ }^{\mathrm{b}} \mathrm{MG}=$ maturity group.

${ }^{c}$ Response of standards to $P$. gregata, averaged across all isolates. above the first trifoliolate leaf [22] on two or more plants) was removed prior to the next inoculation event. To reduce misclassification of BSR-resistant types exhibiting foliar chlorosis-necrosis due to nutrient deficiency, powdery mildew infection, or spider mite damage, reactions of plants with questionable foliar symptoms were verified by splitting the stems lengthwise (22). In these cases, a lack of internal stem browning indicated that the observed foliar chlorosis-necrosis was the result of a factor other than the presence of $P$. gregata.

Following BSR evaluation with two replicates of three isolates of $P$. gregata, data collected from putatively resistant accessions were subjected to an analysis of variance using PROC GLM in SAS (43). An LSD test at the 0.05 probability level was used to test differences in foliar symptom ratings between accessions. Accessions were classified as resistant if the foliar symptom means were not significantly higher than the most resistant standard. Resistant accessions were traced to a specific province of origin in China in an attempt to identify geographical regions associated with high frequency of BSR resistant types.

\section{RESULTS}

Brown stem rot symptoms were observed on all susceptible standards in each replication of each isolate of $P$. gregata, with the exception of cultivar Louisiana Green (Table 2). This standard did not have a foliar symptom mean rating significantly higher than the most resistant standard in this study (Table 2). However, this cultivar was rated susceptible in the first replication of evaluation using $P$. gregata isolate P106 because it had multiple susceptible plants. Resistant standards exhibited resistant reactions to each isolate of $P$. gregata, with the exception of L784094, which was rated susceptible in two replications with one isolate and one replication with a second isolate. The observation that L78-4094 was susceptible to two different isolates of $P$. gregata indicates that the susceptible response is not likely due to physiological specialization of one isolate of $P$. gregata, but that the resistance response in this genotype may be weaker than others included in this test. Although variability in BSR reaction was observed for L78-4094 and Louisiana Green, the other resistant and susceptible standards had consistently low and high foliar symptom means, respectively, in evaluations using all three isolates of $P$. gregata (Table 2).

Of 829 accessions evaluated, 588 were rated susceptible and culled during the screening process because they had at least two susceptible plants in one replicate. The analysis of variance conducted on the pool of remaining, putatively resistant accessions indicated that the responses of these accessions to the three $P$. gregata isolates used in this study were not significantly 
different (there was not a significant isolate by accession interaction). Therefore, replications were pooled across all three isolates of $P$. gregata, and the protected least significant difference (LSD) test was conducted using six replications of data for BSR foliar symptoms. Because a large number of accessions had a resistant response to inoculation with $P$. gregata, the selection criterion for resistance was a foliar symptom mean that was not significantly higher than the most resistant standard. Despite this rigorous selection criterion, only three additional susceptible accessions were identified from the pool of putatively resistant types. Based on results of both methods of susceptibility determination, 241 of $829(\sim 29 \%)$ accessions were identified as BSR resistant (Table 3 ).

Resistant accessions were identified from 13 provinces in China (Table 1). The percentage of resistant types from each province varied between 0 and $67 \%$. A comparison of provinces with a minimum of 40 evaluated accessions revealed that Gansu, Anhui, Jiangsu, and Sichuan had the highest percentage of resistant accessions. These provinces are climatically heterogeneous, with temperatures and rainfall analogous to regions in the United States as diverse as the Great Plains and the humid Southeast (38). However, these provinces share a range in latitude from $30^{\circ}$ to $35^{\circ}$ North. Lohnes et al. (30) reported high frequencies of accessions resistant to Phytophthora sojae in the provinces of Anhui and Jiangsu, and Kyle et al. (27) found a high frequency of soybean accessions resistant to multiple races of $P$. sojae in Hubei, Jiangsu, and Sichuan. Based on information from those studies and the present germ plasm evaluation, future germ plasm collection in the provinces of Anhui, Jiangsu, and Sichuan could yield additional soybean accessions resistant to $P$. sojae and $P$. gregata.

Within the relatively large pool of BSRresistant accessions, accessions were identified with resistance to multiple races of $P$. sojae and preferred agronomic characters, including erect, normal-density pubescence and yellow seed coat (Table 4). Resistance to $P$. sojae and pubescence traits are useful to breeders, as they provide protection against a fungal pathogen and insects, respectively. Yellow seed coat is a trait preferred by many soybean buyers, processors, and consumers.

\section{DISCUSSION}

Previous germ plasm evaluations have identified BSR-resistant accessions. Bachman et al. (3) identified 13 resistant genotypes out of 559 maturity group I to IV accessions from central China (approximately $2.3 \%$ ). Chamberlain and Bernard (6) screened 2,060 soybean genotypes in the field in Illinois and reported one accession, PI 84946-2, that had resistance to BSR. They also selected four other types
Table 3. Soybean accessions from central and southern China with a resistant response to Phialophora gregata isolates PgOh2, SS\#1, and P106

\begin{tabular}{|c|c|c|c|c|c|c|}
\hline \multirow{2}{*}{$\begin{array}{l}\text { Province of } \\
\text { origin } \\
\text { Shanxi }\end{array}$} & \multirow{2}{*}{$\frac{\mathbf{M G}^{\mathbf{a}}}{\mathrm{V}}$} & \multicolumn{5}{|c|}{ Resistant accessions $^{b}$} \\
\hline & & $567290 \mathrm{~B}$ & 567292 & & & \\
\hline \multirow[t]{4}{*}{ Gansu } & V & $567299 \mathrm{~A}$ & $567303 \mathrm{~B}$ & $567310 \mathrm{~A}$ & 567314 & $567316 \mathrm{~A}$ \\
\hline & & $567325 \mathrm{~B}$ & $567326 \mathrm{~B}$ & 567332 & 567333B & $567336 \mathrm{C}$ \\
\hline & & 567338 & 567342 & $567349 \mathrm{~B}$ & $567355 \mathrm{~A}$ & $567355 \mathrm{~B}$ \\
\hline & & 567356 & & & & \\
\hline Ningxia & V & $567370 \mathrm{~B}$ & & & & \\
\hline \multirow[t]{2}{*}{ Shaanxi } & V & $567381 B$ & $567382 \mathrm{~A}$ & $567382 \mathrm{C}$ & 567390 & 567392 \\
\hline & & $567404 \mathrm{~B}$ & $567404 \mathrm{E}$ & 567405 & 567413 & 567414 \\
\hline Hebei & V & $567488 B$ & 567517 & & & \\
\hline \multirow[t]{2}{*}{ Henan } & V & 567625 & 567634 & $567650 \mathrm{D}$ & $567660 \mathrm{~B}$ & $567667 \mathrm{C}$ \\
\hline & & 567670 & 567680 & $567682 \mathrm{~A}$ & $567682 B$ & \\
\hline Jiangsu & IV & $567775 \mathrm{~B}$ & $567779 \mathrm{~B}$ & $587606 \mathrm{~A}$ & $587607 \mathrm{~B}$ & $567608 \mathrm{~A}$ \\
\hline \multirow{6}{*}{ Jiangsu } & $\mathrm{V}$ & 567742B & $567744 \mathrm{C}$ & 567763 & 567764 & 567766 \\
\hline & & $567779 \mathrm{C}$ & 587561 & $587575 \mathrm{~A}$ & $587575 B$ & $587577 \mathrm{C}$ \\
\hline & & 587577D & $587577 \mathrm{E}$ & $587577 \mathrm{G}$ & $587585 \mathrm{~B}$ & $587585 \mathrm{C}$ \\
\hline & & 587585D & $587600 \mathrm{~A}$ & $587604 \mathrm{C}$ & $587606 \mathrm{E}$ & 587619 \\
\hline & & $587620 \mathrm{D}$ & 587639 & $587642 \mathrm{~B}$ & $587643 \mathrm{~B}$ & 587645 \\
\hline & & 587646 & 587648 & 587652 & & \\
\hline \multirow[t]{4}{*}{ Jiangsu } & VI & $587557 \mathrm{~A}$ & $587557 \mathrm{~B}$ & 587562 & $587572 \mathrm{~A}$ & $587572 \mathrm{~B}$ \\
\hline & & $587573 \mathrm{~A}$ & $587583 B$ & 587586 & 587591 & $587595 \mathrm{~A}$ \\
\hline & & 587595B & $587597 \mathrm{~B}$ & $587600 \mathrm{C}$ & $587601 \mathrm{~A}$ & $587601 \mathrm{~B}$ \\
\hline & & $587601 \mathrm{C}$ & $587606 \mathrm{D}$ & $587608 \mathrm{~B}$ & 587640 & 587649 \\
\hline \multirow[t]{5}{*}{ Jiangsu } & VII & 587559B & $587560 \mathrm{~A}$ & $587560 \mathrm{~B}$ & $587560 \mathrm{C}$ & $587565 \mathrm{~B}$ \\
\hline & & $587573 \mathrm{~B}$ & $587575 \mathrm{C}$ & $587579 \mathrm{C}$ & $587592 \mathrm{~A}$ & $587601 \mathrm{E}$ \\
\hline & & 587602 & $587603 B$ & $587603 \mathrm{D}$ & 587613 & 587626 \\
\hline & & $587632 \mathrm{~A}$ & $587632 B$ & $587633 \mathrm{~A}$ & $587633 B$ & $587633 \mathrm{C}$ \\
\hline & & 587634A & 587634B & $587641 \mathrm{~B}$ & 587654 & \\
\hline \multirow[t]{2}{*}{ Jiangsu } & VIII & $587567 \mathrm{~B}$ & $587567 \mathrm{C}^{\mathrm{c}}$ & 587580B & $587596 \mathrm{C}$ & 587599 \\
\hline & & $587605^{\mathrm{c}}$ & & & & \\
\hline Anhui & IV & $587674 \mathrm{~A}$ & & & & \\
\hline Anhui & V & 587667 & 587674B & & & \\
\hline \multirow[t]{2}{*}{ Anhui } & VI & $587664 \mathrm{~A}$ & $587664 \mathrm{~B}$ & 587666 & $587668 \mathrm{~A}$ & 587669 \\
\hline & & $587692 \mathrm{~A}$ & $587700 \mathrm{~B}$ & 587702 & & \\
\hline \multirow[t]{2}{*}{ Anhui } & VII & 587655 & 587656 & 587657 & 587658B & $587670 \mathrm{~A}$ \\
\hline & & 587678 & 587688 & 587692B & $587698 \mathrm{C}$ & 587699 \\
\hline Anhui & VIII & $587703 \mathrm{~A}$ & $587703 \mathrm{~B}$ & & & \\
\hline Shanghai & VI & 587706 & & & & \\
\hline Shanghai & VII & 587708 & 587709A & & & \\
\hline Hubei & V & 587712B & 587713 & 587744 & 587814A & 587814B \\
\hline \multirow[t]{2}{*}{ Hubei } & VI & $587742 \mathrm{C}$ & $587808 \mathrm{~A}$ & $587808 \mathrm{~B}$ & $587814 \mathrm{~F}$ & $587814 \mathrm{G}$ \\
\hline & & $587815 \mathrm{~A}$ & 587824 & 587835 & 587844B & \\
\hline \multirow[t]{3}{*}{ Hubei } & VII & 587731 & 587741 & 587746 & 587762 & 587763 \\
\hline & & 587765 & 587775 & 587776 & $587790 \mathrm{~A}$ & 587791 \\
\hline & & 587838 & 587842 & 587843 & & \\
\hline Hubei & VIII & 587811B & & & & \\
\hline Zhejiang & V & $587892 \mathrm{~A}$ & & & & \\
\hline Zhejiang & VII & 587852 & 587869 & 587871 & 587877 & 587879 \\
\hline & & 587881 & $587883 \mathrm{~A}$ & $587883 \mathrm{~B}$ & 587884 & 587892B \\
\hline & & 587899 & 587904 & 587905 & & \\
\hline Zhejiang & VIII & 587875 & 587888 & 587915D & & \\
\hline Sichuan & IV & 587969 & $587976 \mathrm{C}$ & $587976 \mathrm{D}$ & $587980 \mathrm{C}$ & $587987 \mathrm{C}$ \\
\hline & & $587989 \mathrm{~A}$ & $587989 \mathrm{~B}$ & $587998 \mathrm{~A}$ & $587998 \mathrm{E}$ & $587999 \mathrm{~A}$ \\
\hline & & $587999 \mathrm{C}$ & $588005 \mathrm{~A}$ & $588008 \mathrm{~A}$ & $588015 \mathrm{~A}$ & $588027 \mathrm{~A}$ \\
\hline & & $588027 \mathrm{C}$ & $588027 \mathrm{D}$ & & & \\
\hline Sichuan & $\mathrm{V}$ & $587968 \mathrm{C}$ & 587990 & 587998G & 588007A & $588014 \mathrm{~A}$ \\
\hline Sichuan & VI & $587996 \mathrm{D}$ & $588007 \mathrm{~B}$ & $588017 \mathrm{~A}$ & 588018 & \\
\hline Sichuan & VII & $587992 \mathrm{~A}$ & $587992 \mathrm{~B}$ & $587992 \mathrm{D}$ & $587992 \mathrm{E}^{\mathrm{d}}$ & $587992 \mathrm{~F}$ \\
\hline & & 587993B & $588011 \mathrm{E}$ & $588014 \mathrm{C}$ & 588014D & 588020 \\
\hline & & $588032 \mathrm{~B}$ & & & & \\
\hline Sichuan & VIII & $587992 \mathrm{G}^{\mathrm{d}}$ & 588031 & $588032 \mathrm{C}$ & 588032D & \\
\hline Guangdong & IV & $588050 \mathrm{~A}$ & $588052 B$ & & & \\
\hline Guangdong & VI & $588050 \mathrm{~B}$ & 588051 & $588053 \mathrm{~A}$ & $588053 \mathrm{~B}$ & \\
\hline
\end{tabular}

${ }^{\text {a }} \mathrm{MG}=$ maturity group.

${ }^{b}$ Accessions were classified as resistant if (i) one or fewer susceptible plants were identified in each replicate of each challenge with individual $P$. gregata isolates, PgOhs, SS\#1, and P106, and (ii) if the average foliar symptom rating across isolates was not significantly higher than the average foliar symptom rating of the most resistant standard.

${ }^{c}$ Not evaluated with $P$. gregata isolate SS\#1.

${ }^{\mathrm{d}}$ Not evaluated with $P$. gregata isolate $\mathrm{PgOh} 2$. 
that were later shown to have BSR resistance $(35,50)$. Nelson et al. (36) screened over 3,400 accessions in maturity groups 000 to IV and selected $51(1.5 \%)$ putatively resistant types for replicated testing. tested material was classified in maturity groups IV or earlier, and relatively small percentages of genotypes were found with resistant reactions. In the present study, however, most accessions were classified in maturity groups IV to VII, and a relatively large percentage of the genotypes $(29 \%)$ had resistant reactions.

One possible explanation for the large percentage of resistant types identified in this study is the late maturity of the evaluated accessions. Gray (20) found that susceptibility to BSR increases as the plant approaches reproductive development. This dependence of BSR symptom development on physiological age of the plant would explain a trend of decreasing susceptibility with increasing relative maturity. However, this trend was not observed in this study, as approximately equal percentages of accessions in maturity groups IV to VIII were classified as susceptible (data not included). These results agree with those of Bachman et al. (3) and Nelson et al. (36), which identified susceptible genotypes in a range of maturity groups.

Another hypothesized explanation for the high percentage of resistant accessions in the present evaluation is systemic infection with Soybean mosaic virus (SMV) in putatively resistant accessions. Tachibana and Card (51) reported an inverse relationship between SMV (indicated by seed coat mottling) and BSR resistance. Because SMV symptoms may not be expressed under certain environmental conditions (49), the virus could have been present, affecting BSR symptom development. To determine if SMV was present in putatively resistant accessions, double antibody sandwich In each of these germ plasm evaluations,

ELISA was performed on a subset of the pool of resistant genotypes. Of 50 accessions assayed (approximately 10 accessions from each maturity group IV to VIII), only three were infected with SMV (data not included). These results suggest that SMV infection was not responsible for the majority of BSRresistant reactions exhibited by the pool of evaluated germ plasm.

Brown stem rot of soybean has been identified in cooler climates, including the north central United States and Canada $(7,8,12,13,23-26,28)$, and in warmer regions, including the southeastern United States $(11,21,25,39,41,42)$, Mexico (34), and Egypt (49). Because $P$. gregata is present and BSR can develop in warmer regions, one factor contributing to the relatively small impact of BSR in the southern United States (58) versus the northern United States (10) could be a relatively high proportion of resistant germ plasm that has served as progenitors for southern cultivars. Gizlice et al. (17) reported that two Chinese soybean ancestor lines, cv. CNS and cv. S-100, together contributed $46 \%$ of the genetic base of southern cultivars. Three other cultivars, Ogden, Jackson, and Roanoke, contributed another $23.5 \%$ to the genetic base of southern soybean cultivars. All of these contributors are classified as maturity group $\mathrm{V}$ or later. Although no study has compared the BSR reactions of these lines, the results of this study and previous germ plasm evaluations suggest that germ plasm lines adapted to the southern United States are more likely to be resistant to BSR than those in earlier maturity groups.

Gizlice et al. (16) found that cultivars in northern and southern regions of the United States formed distinct gene pools. Given this information and the concerns about narrow genetic base of modern soybean cultivars (50), soybean breeders will likely attempt to integrate northern and southern germ plasm

Table 4. Chinese soybean accessions with resistance to Phialophora gregata and multiple races of Phytophthora sojae and preferred agronomic characters including erect, normal-density pubescence and yellow seed coat

\begin{tabular}{lcll}
\hline Accession & $\begin{array}{c}\text { Maturity } \\
\text { group }\end{array}$ & Province & $\begin{array}{c}\text { Resistance to races } \\
\text { of } \boldsymbol{P} \text {. soja } \boldsymbol{e}^{\mathbf{a}}\end{array}$ \\
\hline PI567316A & IV & Jiangsu & 1357 \\
PI567338 & IV & Henan & 134571325 \\
PI567342 & IV & Henan & 512 \\
PI567405 & V & Jiangsu & 134571325 \\
PI567742B & IV & Anhui & 134571325 \\
PI567763 & IV & Shandong & 1345713 \\
PI587606E & V & Jiangsu & 1371017 \\
PI587814A & V & Hubei & 13571017 \\
PI587814F & VI & Hubei & 13457101725 \\
PI587814G & VI & Hubei & 13457101725 \\
PI587992B & VII & Sichuan & 135717 \\
PI588011E & VII & Sichuan & 13710 \\
PI588014A & V & Sichuan & 1371017 \\
PI588014D & VII & Sichuan & 13457 \\
PI588027A & IV & Sichuan & 13710121720 \\
PI588027C & IV & Sichuan & 13710121720 \\
PI588032C & VIII & Sichuan & 1345725 \\
PI588032D & VIII & Sichuan & 1345725 \\
\hline
\end{tabular}

${ }^{a}$ Responses to $P$. sojae reported by Kyle et al. (27). in the future. Based on data collected in the present study and assuming BSR resistance in southern germ plasm is heritable, integration of BSR resistance into northern germ plasm could be accomplished using traditional breeding methods.

Resistance to brown stem rot of soybean has been shown to be controlled by dominant alleles and is highly heritable if environmental variation can be reduced $(22,44,56)$. Sebastian and Nickell (44) hypothesized that variation in rate of BSR development in different susceptible genotypes may be attributed to differences in genetic background. Eathington et al. (14) and Waller et al. (52) also hypothesized the presence of modifier genes for BSR resistance. The present study and a germ plasm evaluation conducted by Bachman et al. (3) indicate a broad range in the level of BSR resistance in soybean germ plasm. Responses to $P$. gregata ranged from apparent immunity to plant death (data not included), providing further evidence for modifier genes or allelic variation at resistance loci.

In the planning phase of this study, a decision had to be made whether to evaluate accessions with a single isolate of $P$. gregata and repeat that experiment three times, or to test accessions in three experiments, each using a unique, highly pathogenic defoliating isolate. Given the limited resources available for this study, the high heritability associated with greenhouse BSR screening, and the availability of three unique $P$. gregata isolates of known pathogenicity, it seemed evident that evaluation with multiple isolates would provide the best information on resistance levels and resistance stability across isolates for these accessions. While the goal of this study was to evaluate reactions of germ plasm to $P$. gregata and not to measure isolate differences, the inclusion of and testing with three isolates from three states increased our confidence that the response to a given isolate represented a characteristic response to $P$. gregata. Despite variability in host resistance responses to $P$. gregata, there were no significant interactions between the soybean accessions and the three isolates of $P$. gregata used in this study. Although physiological specialization and variation in virulence of $P$. gregata have been documented $(18,31,40,48,57)$, these phenomena were not observed in this study.

Soybean genotypes can be evaluated reliably for BSR resistance using greenhouse screening procedures, although this method is laborious $(3,46)$. Methods have also been developed to assay for the presence of BSR resistance loci using molecular markers $(5,54)$. However, the evaluation of traits using molecular markers alone may not be reliable in populations other than those in which the markers were identified. Apparent marker-gene linkages could be removed through recombination (reduction 
in linkage disequilibrium) (29), or marker polymorphism simply may not exist between genetically diverse populations under evaluation $(9,47)$. In the present germ plasm evaluation, $90 \%$ of the susceptible accessions were identified with a single replication of two to five inoculated plants. In addition, responses of putatively resistant accessions to three different isolates of $P$. gregata were not significantly different. Based on these findings, future soybean BSR evaluation could be conducted using as few as two replications of a single reliable defoliating isolate of $P$. gregata. This conclusion was also made by Sebastian et al. (46), who stated that two replications (pots) of data from greenhouse evaluation were predictive of the field reaction to BSR. Until molecular markers can be reliably utilized across populations and proven to be predictive of phenotypic manifestations of associated resistance genes, phenotypic evaluation for BSR reaction will be necessary.

\section{ACKNOWLEDGMENTS}

We thank Glen L. Hartman for the use of his laboratory resources, and Beatrice Curio-Penny for conducting the ELISA for soybean mosaic virus.

\section{LITERATURE CITED}

1. Adee, E. A., Grau, C. R., and Oplinger, E. S. 1995. Inoculum density of Phialophora gregata related to severity of brown stem rot and yield of soybean in microplot studies. Plant Dis. 79:68-73.

2. Allington, W. B., and Chamberlain, D. W. 1948. Brown stem rot of soybean. Phytopathology 38:793-802.

3. Bachman, M. S., Nickell, C. D., Stephens, P. A., and Nickell, A. D. 1997. Brown stem rot resistance in soybean germ plasm from central China. Plant Dis. 81:953-956.

4. Bachman, M. S., Nickell, C. D., Stephens, P. A., Nickell, A. D., and Gray, L. E. 1997. The effect of $R b s_{2}$ on yield of soybean. Crop Sci. 37:1148-1151.

5. Bachman, M. S., Tamulonis, J. P., Bent, A. F., and Nickell, C. D. 1999. Identification of SSR markers linked to a putative brown stem rot resistance gene cluster in soybean. Plant Animal Genome VII Conf. VII. Abstr. 139.

6. Chamberlain, D. W., and Bernard, R. L. 1968. Resistance to brown stem rot in soybeans. Crop Sci. 8:728-729.

7. Crall, J. M. 1947. Brown stem rot of soybeans in Missouri. Plant Dis. Rep. 32:14.

8. Crall, J. M. 1951. Soybean diseases in Iowa in 1950. Plant Dis. Rep. 35:320-321.

9. Cregan, P. B., Jarvik, T., Bush, A. L., Shoemaker, R. C., Lark, K. G., Kahler, A. L., Kaya, N., VanToai, T. T., Lohnes, D. G., Chung, J., and Specht, J. E. An integrated genetic linkage map of the soybean genome. Crop Sci. In press.

10. Doupnik, B., Jr. 1993. Soybean production and disease loss estimates for north central United States from 1989 to 1991. Plant Dis. 77:1170-1171.

11. Dunleavy, J. M. 1966. Factors influencing spread of brown stem rot of soybeans. Phytopathology 56:298-300.

12. Dunleavy, J. M., Chamberlain, D. W., and Ross, J. P. 1966. Soybean Diseases. Page 39 in: U.S. Dep. Agric. Agric. Handb. 302.

13. Dunleavy, J. M., and Lambe, R. C. 1967. Incidence of brown stem rot of soybeans in Iowa. Plant Dis. Rep. 51:438-441.

14. Eathington, S. R., Nickell, C. D., and Gray, L. E. 1995. Inheritance of brown stem rot resis- tance in soybean cultivar BSR 101. J. Hered. 86:55-60.

15. Fehr, W. R., Caviness, C. E., Burmood, D. T., and Pennington, J. S. 1971. Stage of development descriptions for soybeans, Glycine $\max ($ L.) Merrill. Crop Sci. 11:929-931.

16. Gizlice, Z., Carter, T. E., Jr., and Burton, J. W. 1993. Genetic diversity in North American soybean: I. Multivariate analysis of founding stock and relation to coefficient of parentage. Crop Sci. 33:614-620.

17. Gizlice, Z., Carter, T. E., Jr., and Burton, J. W. 1994. Genetic base for North American public soybean cultivars released between 1947 and 1988. Crop Sci. 34:1143-1151.

18. Gray, L. E. 1971. Variation in pathogenicity of Cephalosporium gregatum isolates. Phytopathology 61:1410-1411.

19. Gray, L. E. 1972. Effect of Cephalosporium gregatum on soybean yield. Plant Dis. Rep. 56:580-581.

20. Gray, L. E. 1974. Role of temperature, plant age, and fungus isolate in the development of brown stem rot in soybeans. Phytopathology 64:94-96.

21. Hamilton, R. I., and Boosalis, M. G. 1955. Asexual reproduction in Cephalosporium gregatum. Phytopathology 45:293-294.

22. Hanson, P. M., Nickell, C. D., Gray, L. E., and Sebastian, S. A. 1988. Identification of two dominant genes conditioning brown stem rot resistance in soybean. Crop Sci. 28:41-43.

23. Hildebrand, A. A. 1948. An occurrence of brown stem rot of soybean in Ontario. Sci. Agric. 28:261-263.

24. Johnson, H. W. 1950. Plant disease research on forage crops in the Bureau of Plant Industry, Soils, and Agricultural Engineering. Plant Dis. Rep. Suppl. 190:42-59.

25. Johnson, H. W., Chamberlain, D. W., and Lehman, S. G. 1954. Disease of soybeans and methods of control. U.S. Dep. Agric. Circ. 931.

26. Kernkamp, M. F., and Gibbler, J. W. 1951. Diseases of soybeans new to Minnesota. Plant Dis. Rep. 35:510.

27. Kyle, D. E., Nickell, C. D., Nelson, R. L., and Pedersen, W. L. 1998. Response of soybean accessions from provinces in southern China to Phytophthora sojae. Plant Dis. 82:555-559.

28. Lai, P. V., and Dunleavy, J. M. 1969. Sporulation of Cephalosporium gregatum on naturally infested soybean straw. Phytopathology 59:343-345.

29. Lande, R., and Thompson, R. 1990. Efficiency of marker-assisted selection in the improvement of quantitative traits. Genetics 124:743-756

30. Lohnes, D. G., Nickell, C. D., and Schmitthenner, A. F. 1996. Origin of soybean alleles for Phytophthora resistance in China. Crop Sci. 36:1689-1692.

31. Mengistu, A., and Grau, C. R. 1986. Variation in morphological, cultural, and pathological characteristics of Phialophora gregata and Acremonium sp. recovered from soybean in Wisconsin. Plant Dis. 70:1005-1009.

32. Mengistu, A., and Grau, C. R. 1987. Seasonal progress of brown stem rot and its impact on soybean productivity. Phytopathology 77:1521-1529.

33. Mengistu, A., Grau, C. R., and Gritton, E. T. 1986. Comparison of soybean genotypes for resistance to and agronomic performance in the presence of brown stem rot. Plant Dis. 70:1095-1098.

34. Morgan, F., and Dunleavy, J. M. 1966. Brown stem rot of soybeans in Mexico. Plant Dis. Rep. 50:598-599.

35. Nelson, R. L., and Bernard, R. L. 1983. Germplasm collection, management, and evaluation. The subgenus: Soja. Proc. First China/USA Soybean Sympos. B. J. Irwin, J. B. Sinclair, and J. L. Wang, eds. INTSOY Se- ries 25:71-72.

36. Nelson, R. L., Nickell, C. D., Orf, J. H., Tachibana, H., Gritton, E. T., Grau, C. R., and Kennedy, B. W. 1989. Evaluating soybean germ plasm for brown stem rot resistance. Plant Dis. 73:110-114.

37. Nicholson, J. F., Sinclair, J. B., and Thapliyal, P. N. 1973. The effect of rate of planting on incidence of brown stem rot in soybean. Plant Dis. Rep. 57:269-271.

38. Nuttonson, M. Y. 1947. Ecological crop geography of China, and its agro-climatic analogues in North America. American Institute of Crop Ecology, Washington, DC.

39. Phillips, D. V. 1970. Incidence of brown stem rot of soybean in Georgia. Plant Dis. Rep. 54:987-988.

40. Phillips, D. V. 1973. Variation in Phialophora gregata. Plant Dis. Rep. 57:1063-1065.

41. Phillips, D. V., and Ross, J. P. 1968. Incidence of brown stem rot of soybeans in North Carolina. Plant Dis. Rep. 52:895-896.

42. Ross, J. P., and Smith, T. J. 1963. Brown stem rot of soybean in North Carolina and Virginia. Plant Dis. Rep. 47:329.

43. SAS Institute. 1985. SAS User's Guide: Statistics. 5th ed. SAS Institute, Cary, NC.

44. Sebastian, S. A., and Nickell, C. D. 1985. Inheritance of brown stem rot resistance in soybeans. J. Hered. 76:194-198.

45. Sebastian, S. A., Nickell, C. D., and Gray, L. E. 1985. Efficient selection for brown stem rot resistance in soybeans under greenhouse screening conditions. Crop Sci. 25:753-757.

46. Sebastian, S. A., Nickell, C. D., and Gray, L E. 1986. Relationship between greenhouse and field ratings for brown stem rot reaction in soybean. Crop Sci. 26:665-667.

47. Shoemaker, R. C., Guffy, R. D., Lorenzen, L. L., and Specht, J. E. 1992. Molecular genetic mapping of soybean: Map utilization. Crop Sci. 32:1091-1098.

48. Sills, G. R., Gritton, E. T., and Grau, C. R. 1991. Differential reactions of soybean genotypes to isolates of Phialophora gregata. Plant Dis. 75:687-690.

49. Sinclair, J. B., and Backman, P. A. 1989. Compendium of Soybean Diseases. American Phytopathological Society, St. Paul, MN. pp. 29-30.

50. Sneller, C. H. 1994. Pedigree analysis of elite soybean lines. Crop Sci. 34:1515-1522.

51. Tachibana, H., and Card, L. C. 1972. Brown stem rot resistance and its modification by soybean mosaic virus in soybeans. Phytopathology 62:1314-1317.

52. Waller, R. S., Nickell, C. D., Drzycimski, D. L., and Miller, J. E. 1991. Genetic analysis of the inheritance of brown stem rot resistance in the soybean cultivar Asgrow A3733. J. Hered. 82:412-417.

53. Waller, R. S., Nickell, C. D., and Gray, L. E. 1992. Environmental effects on the development of brown stem rot in soybean. Plant Dis. 76:454-457.

54. Webb, D. M. 1997. Brown Stem Rot Resistance in Soybeans. Pioneer Hi-Bred International, Inc., Des Moines, IA: 534,091. U.S. patent 5,689,035, 09-26-1995.

55. Weber, C. R., Dunleavy, J. M., and Fehr, W. R. 1966. Influence of brown stem rot on agronomic performance of soybeans. Agron. J. 258:519-520.

56. Willmot, D. B., and Nickell, C. D. 1989. Genetic analysis of brown stem rot resistance in soybean. Crop Sci. 29:672-674.

57. Willmot, D. B., Nickell, C. D., and Gray, L. E. 1989. Physiologic specialization of Phialophora gregata on soybean. Plant Dis. 73:290294.

58. Wrather, J. A., and Sciumbato, G. L. 1995. Soybean disease loss estimates for the southern United States during 1992 and 1993. Plant Dis. 79:84-85. 